\title{
How Do High School Seniors See Their Future? Parental and Peer Influences on Their Personal and Professional Plans
}

\author{
Mihai-Bogdan Iovu ${ }^{1 *}$ \\ ${ }^{1}$ Babeş-Bolyai University of Cluj-Napoca, Department of Social Work, 12821 Decembrie 1989 Bld., 400604 Cluj- \\ Napoca, Romania
}

KEYWORDS

Adolescents

Friend support

Future planning

Parent support

\section{A BSTRACT}

Statement of problem: Future orientation is a multidimensional and multistage phenomenon. Studies have indicated that how adolescents anticipate and plan for their future is greatly influenced by the particular context in which they are placed, but most of the research in this area has been conducted with adolescents from western cultures. Aim: This study examined the personal (getting married, moving with the partner, having a child) and professional (having a job, starting a business) future planning of adolescents in contemporary Romania and its relation with adolescents' background and with parents and friends support. Method: We administered a questionnaire measuring their future orientation and support from parents and friends to 3524 high school seniors from Romania. Results: Adolescents' personal future planning varies across different life domains. Females were more likely to plan moving with the partner and getting married, while males were more likely to plan a career option. Family had an effect on professional plans, but the effect is negative, while friends were positive associated with all the future planning.

\section{Introduction}

Adolescence is often conceptualized as a pivotal period for youth in preparation for adulthood. Multiple systems are involved in this preparation

\footnotetext{
*Contact addresses: iovu.mihai@socasis.ubbcluj.ro (M. B. Iovu)
} 
and orientation, resulting in a complex process which operates to propel adolescents toward thinking about and making plans for later adult attainments. Therefore, on one hand we have 'adolescence' as a time when significant decisions concerning life are made (Stattin and Kerr 2001). Having this in mind, thinking about the future and oneself in the future might have a bigger role during adolescence than during any other developmental life stage (Trempala and Malmberg 2002). On the other hand, according to popular stereotypes, 'adolescence' is a period when youth are notoriously shortsighted, oriented to the immediate rather than the future, unwilling or unable to plan ahead, and less capable than adults at envisioning the longer term consequences of their decisions and actions (Steinberg et al. 2009).

To date, there is a wide literature providing both theoretical understanding and empirical data on the timing and occurrence of major life events as marriage and parenthood (Seltzer 2000). Previous studies showed that adolescents' future orientation is not only influenced by their cognitive maturation, but also shaped by the culture and the context where they grow up (Rarasati, Hakim and Yuniarti 2012). Most of the literature is focused on adolescents' choices of future education major or career (Farmer 1985). In this light, one Romanian study focusing on adolescents' perceived career competence, motives, and values showed that social work students are firstly driven by the value of helping others, but also are driven by the need to integrate professional, family and personal issues in a consistent manner and seek careers that will provide constant stimulation and difficult problems that they can solve (Runcan and Goian 2013). Teenage aspirations are a good predictor of later adult occupational attainment: young people with high aspirations are more likely than their less ambitious peers to enter a professional or managerial career (Schoon and Parsons 2002). Moreover, the career one chooses affects other important decisions like being involved in romantic relationships and/or having a child. Daughters' expectations regarding the timing of their transition to parenthood are shaped by factors other than the family such as career plans, friends' attitudes, and whether 
they are in an intimate relationship in which they would want to take on the role of motherhood (Starrels and Holm 2000). Unlike females, men's life course trajectories generally follow a more ordered sequence in terms of career development and family formation (Maines and Hardesty 1987). Other studies showed that American college students generally tend to wish a prestigious occupation and a high economic status (Sipe, Johnson and Fisher 2009). McCabe and Barnett's study (2000) showed that African American young adolescents were more detailed, optimistic, and realistic about their future careers than their romantic and family relationships and felt that they had more control over careers than over relationships. According to Barnet, Gareis, James and Steele (2003), students whose mothers worked during their early childhood and students who planned to start a family later, face less career-marriage conflict.

We may conclude different expectations and desires about marriage, children, jobs, moving away are products of many influences. There is a very strong concurrent and longitudinal correlational evidence of the predictive importance of connectedness with family and peers for positive youth development (Fisher and Griggs 1995). Parents have a strong influence on their children's lives and can shape adolescents' career development, occupational plans and attitudes toward job success (Steinberg 2004). Also, supportive friends or peers have a crucial influence on the future planning of students and in making key life decisions (Felsman and Blustein 1999). Davies and Kandel (1981) found that peers' influence on adolescents' future plans did exist. However, parents' aspirations for their children had a much stronger effect than peer influence did. Another study carried on Romanian youth showed that both peer and family support influence future personal plans of adolescents in the area of getting married, having a child or moving with the partner (Iovu et al. 2013). These findings suggest that the absence of such support could negatively affect students' future planning and development. In general, social support from key-persons predicts a relatively smooth transition into key adult roles as intimate partner, spouse, 
parent, worker, and active community member (e.g., Cairns and Cairns 1994; Conger et al. 2000; Furstenberg et al. 1999).

\section{Methods}

\section{Aim}

Our current interest is in Romanian high school seniors. This is an emerging topic on Romanian research agenda and therefore there is little research focusing on emerging adults. From the issues portraying transition to adult roles, we chose to focus on their overall thinking of their future plans. This study complements recent results on Romanian adolescents' orientation and preparation for the future by examining their personal plans (e.g. moving with the partner, family formation, having children) and professional plans (e.g. finding a job, starting a business) (see Iovu 2013; Iovu et al. 2013; Roth et al. 2013). The main research question was in what extent are future personal and professional plans influenced by relationship with family members and friends or by individual characteristics?

\section{Sources of data and sampling}

Using an online platform, during October 2012 and February 2013, data was collected using a national representative sample of $12^{\text {th }}$ graders. A multistratified random sampling procedure was employed. Initially, we aimed at reaching 6611 high school seniors (according the official data on the enrolment rate for the 2009/2010 school year). The first stratum referred to the 'region of development'. The projected sample included 882 students from North-West, 808 from Centre, 1305 from North-East, 633 from SouthEast, 831 from South, 458 from Bucharest and Ilfov region, 1083 from SouthWest, and 611 from West. The second stratum included 'county': 2 from each region, except North-West with 3: Bihor, Cluj, Sălaj, Sibiu, Covasna, Iaşi, Bacău, Galați, Constanța, Argeş, Teleorman, Bucureşti, Ilfov, Dolj, Vâlcea, Timiş, Caraş-Severin. The second stratum included 'residency', aiming for 
6061 students from urban areas and 550 from rural. The last stratum included 'the school and classroom educational path': 136 classes with theoretical training path, 143 classes with industrial path, 43 economic and 21 other paths (e.g. agricultural, forestry, sport, theology, arts etc). 91 schools and 346 classes were reached. Out of expected sample volume we reached 4262 respondents of which we eliminated subjects having less than $1 / 3$ completed questions. Therefore, the valid sample reached 3524 high school seniors.

\section{Sample profile}

There were more female students in the sample (58.2\% compared to $41.8 \%$ ). By the age $15,57.4 \%$ declared were living in urban settings and $41.8 \%$ in rural areas. The students that lived in another country were underrepresented in the sample. In terms of ethnicity and religious affiliation, the large majority declared themselves as Romanians (91.6\%) and orthodox $(78.9 \%)$. The majority of respondents came from families with both members present (81.7\% parents had never split up).

\section{Measures}

Four continuous explanatory variables (family togetherness, home academic environment, friend support and peer group acceptance) were employed. The actual scales were taken from the School Success Profile (Hărăguş, Roth and Dămean 2010). Future plans was defined as the outcome variable.

Family togetherness scale $(M=1.34, S D=.43)$ measured the degree youth report that the people in their home feel a sense of emotional closeness and bonding with one another, do things together, and work together to solve problems. The scale uses a 3-point Likert response format $(1=$ Not at all, $2=A$ little, $3=A$ lot $)$. By summing the response of the 7 associated items a general score was computed with higher score indicating greater family support. The Cronbach's alpha reliability coefficient for the family togetherness scale for the current data is .90 . 
Home academic environment scale [HAE] $(M=1.71, S D=.46)$ measured the degree youth report that they discuss different topics (e.g. their courses or programs at school, their school-related activities, current events and politics, and their plans for the future) with the adults who live in their home. The 8-item scale used a 3-pomit Likert response structure $(1=$ Never, 2 = Once or twice, $3=$ More than twice). By adding the scores, a total score was generated with high values indicating better communication patterns. The Cronbach's alpha for the scale was .85 .

Friend support scale $(M=1.46, S D=.52)$ measured the degree youth perceives their friends as trustworthy and supportive and as responsive to their needs and feelings. The combined 5-item scale utilized a 3-point Likert response format for each item $(1=$ Not at all, $2=A$ little, $3=A$ lot $)$. The range of possible scores was 5 to 15 , with a higher score indicating a greater peergroup support. In the current study, the Cronbach's alpha reliability coefficient for the peer group support scale is .92 .

Peer-group acceptance scale $(M=1.45, S D=.33)$ measured the degree youth feel accepted by their peers, able to be themselves, and able to resist peer pressure. The scale used an 8-item structure with response categories being: $1=$ Not at all, $2=A$ little, $3=A$ lot . By adding the individual scores, a total score ranging from 8-24 was generated with high numbers representing increased peer-pressure. The Cronbach's alpha reliability coefficient for the scale is .71.

Personal future planning was a categorical variable $(1=$ Yes, $2=\mathrm{No})$ identifying adolescents' plans for the next two-three years. The instrument included several areas: moving with the partner, getting married, having a child, having a job, and starting their own business.

Demographics included gender (male/female), family structure (twoparent/single-parent units), and residency of the child (urban/rural).

\section{Procedure}

During an initial contact with the high school seniors from the selected units, the interviewer explained the aim of the project. Students were then asked 
for their consent, their phone number and an e-mail address in order to be further contacted by the research team. Students received an e-mail with a link to the questionnaire and instructions for filling in. they were also contacted by phone reminding and asking them to fill the questionnaire. For students who gave their consent, but did not have internet access, the school provided free laboratory access. When this was not possible, students filled a pen-and-paper version of the online instrument (243 cases). In order to assure the confidentiality, anonymity, and privacy of the responses, students were told that data will be available only to the members of the project and a contact number was provided for addressing future concerns. Subjects were asked to make sure that they filled in the entire questionnaire in privacy. Answers were then imported into SPSS and used in analysis.

\section{Data analysis}

Data were analysed using the SPSS version 18 for Microsoft Windows. Response frequencies for the survey questions were determined and displayed in tabular formats. After examining the response frequencies, and before examining the relations between variables, some variable categories were collapsed or recoded in order to allow multiple logistic regression analysis.

\section{Analysis and Results}

\section{Personal future plans of adolescents}

We noticed a wide variability in adolescents' future personal plans for the near future: $36.9 \%$ planed moving with the partner, $14.6 \%$ planed getting married and $10.3 \%$ were planning having a child. Professional plans were also well defined: more than two thirds (78.6\%) was planning having a job and almost half of them $(40.4 \%)$ was planning to start their own business. To investigate whether males/females, living in urban/rural areas and coming from two-parent/single-parent family differ on their future planning, a chi- 
square analysis was run. Males and females were significantly different on whether they plan moving with the partner $\left[\chi^{2}(1, N=2039)=27.16, p<.01\right]$, getting married $\left[\chi^{2}(1, N=2447)=26.76, p<.01\right]$, and starting their own business $\left[\left(X^{2}(1, N=1970)=39.81, p<.01\right]\right.$. Males were more likely than expected under the null hypothesis to plan having their own business than females, while females were more likely to focus more on having familyrelated plans. Youth living in urban and rural areas were also significantly different on whether they plan getting married $\left[\chi^{2}(1, N=2423)=18.20, p<\right.$ $.01)]$, having a child $\left.\left[\chi^{2}(1, N=2520)=5.02, p<.05\right)\right]$, having a job $\left[\left(\chi^{2}(1, N=\right.\right.$ $2622)=33.69, p<.01)]$, and starting their own business $\left[\chi^{2}(1, N=1952)=\right.$ 16.32, $p<.01)$ ]. Adolescents from rural areas were more likely to plan all these things than peers from urban settings. Coming from two-parent or single-parent families significantly differentiate youth in planning moving with the partner $\left.\left[\chi^{2}(1, N=1661)=4.50, p<.05\right)\right]$, having a job $\left[\chi^{2}(1, N=\right.$ $2162)=8.52, p<.01)]$, and having a business in the near future $\left[\chi^{2}(1, N=\right.$ $1620)=4.22, p<.05)$ ]. Those coming from single-parent family structures were more likely to plan moving with the partner, while those coming from two-parent family structures were more likely to focus more on the career related plans.

\section{Relationships with family members and friends}

The majority of youth reported that family members help developing a sense of emotional closeness and bonding with one another, do things together, and work together to solve different problems (Table 1). The smallest percentage was reported for 'doing activities together', but considering the age of subjects, this was expected. Significant differences in reported level of family togetherness were according to family structure $[t(29.38)=-3.87, p<$ $.001]$. 
Table 1. Descriptive analysis of family togetherness scale

\begin{tabular}{lrrr}
\hline \multicolumn{1}{c}{ Members of my family... } & $\begin{array}{c}\text { Not at all } \\
(\mathbf{\%})\end{array}$ & \multicolumn{1}{c}{$\begin{array}{c}\text { A little } \\
(\mathbf{\%})\end{array}$} & \multicolumn{1}{c}{$\begin{array}{c}\text { A lot } \\
(\%)\end{array}$} \\
\hline support one another & 2.1 & 16.9 & 80.9 \\
\hline give each other plenty of time and attention & 4.4 & 32.1 & 63.5 \\
\hline talk openly andlisten to one another & 4.4 & 25.3 & 70.4 \\
\hline feel loved and cared for by one another & 3.2 & 18.6 & 78.2 \\
\hline do things together & 7.8 & 44 & 48.3 \\
\hline play and laugh together & 4.7 & 27.3 & 68.1 \\
\hline work together to solve problems & 3.4 & 19.2 & 77.4 \\
\hline
\end{tabular}

As for communication with family members on different topics, there was a bigger variability (Table 2). The majority of them discussed these topics at least once in the last month. 'Politics' was the topic least discussed with adults, while 'plans for the future', 'career choices', and 'plans for college' were most discussed topics. Significant differences in reported level of family communication were according to gender $[t(2615.44)=-9.59, p<$ $.001]$, family status $[t(2472)=-2.82, p<.01]$, and residency $[t(2988)=-4.20, p<$ $.001]$.

Table 2. Descriptive analysis of home academic environment scale

\begin{tabular}{lrrr}
\hline $\begin{array}{c}\text { During the past 30 days, you have discussed } \\
\text { the following w ith an adult who lives with } \\
\text { you... }\end{array}$ & $\begin{array}{c}\text { Never } \\
\mathbf{( \% )}\end{array}$ & $\begin{array}{c}\text { Once or } \\
\text { tw ice } \\
(\%)\end{array}$ & $\begin{array}{c}\text { More } \\
\text { than } \\
\text { twice } \\
(\%)\end{array}$ \\
\hline selecting courses or programs at school & 15 & 42.3 & 42.7 \\
\hline school activities or events that interest you & 11.8 & 40.4 & 47.8 \\
\hline things you've studied in class & 20.4 & 45.7 & 34 \\
\hline current events & 13.2 & 43.7 & 43.1 \\
\hline politics & 62.8 & 27.8 & 9.4 \\
\hline your plans for the future & 5.8 & 28.6 & 65.6 \\
\hline work/car eer choices & 6.3 & 29.9 & 63.8 \\
\hline your plans for college & 6.6 & 28.9 & 64.5 \\
\hline
\end{tabular}

Similar levels of support were also reported for the peer-group (Table 3). More than fifty percent of adolescents declared they benefit a lot from 
peer-group support. Significant differences were reported for gender $[t(3042)=-2.43, p<.01]$, and residency $[t(2642.38)=-7.78, p<.001]$.

Table 3. Descriptive analysis of friend support scale

\begin{tabular}{lrrr}
\hline & $\begin{array}{c}\text { Not at all } \\
(\%)\end{array}$ & $\begin{array}{c}\text { A little } \\
\text { (\%) }\end{array}$ & $\begin{array}{c}\text { A lot } \\
\text { (\%) }\end{array}$ \\
\hline I can trust my friends & 4.9 & 37.6 & 57.5 \\
\hline I am able to tell my problems to my friends & 7.9 & 38.6 & 53.4 \\
\hline I feel close to my friends & 4.4 & 33.4 & 62.2 \\
\hline I can count on my friends for support & 5 & 34.4 & 60.6 \\
\hline I can talk to my friends about things that bother me & 5.4 & 33.2 & 61.4 \\
\hline
\end{tabular}

In general, adolescents feel accepted by their peers and the pressure they exert is low (below 7\% on all items except for the last one) (Table 4). Significant differences in reported level of peer group acceptance are again according to gender $[t(2464.84)=-11.35, p<.001]$, and residency $[t(2633.33)=$ $-3.54,<.001]$.

Table 4. Descriptive analysis for the peer-group acceptance scale

\begin{tabular}{lrrr}
\hline & $\begin{array}{c}\text { Not at } \\
\text { all } \\
(\mathbf{\%})\end{array}$ & $\begin{array}{c}\text { A } \\
\text { little } \\
\mathbf{( \% )}\end{array}$ & $\begin{array}{c}\text { A lot } \\
\mathbf{( \% )}\end{array}$ \\
\hline I do things just to be popular with my friends & 40.3 & 53.7 & 6 \\
\hline $\begin{array}{l}\text { I let my friends talk me into doing things I really } \\
\text { don't want to do }\end{array}$ & 64.7 & 32.8 & 2.5 \\
\hline I am made fun of by my friends & 48.2 & 46.7 & 5.1 \\
\hline I am picked on by my friends & 81 & 15.8 & 3.2 \\
\hline $\begin{array}{l}\text { I find it difficult to be myself when I am with my } \\
\text { friends }\end{array}$ & 83.8 & 13.4 & 2.8 \\
\hline I try hard to impress my friends & 67.7 & 28 & 4.3 \\
\hline I tend to go along with the crowd & 44.9 & 48.9 & 6.2 \\
\hline I wish my friends show me more respect & 49.8 & 35.4 & 14.8 \\
\hline
\end{tabular}

Table 5 summarizes the statistical significant differences. We noticed that compared to girls, male reported more support from peers $(M=1.48)$, more communication with parents $(M=1.79)$, and more friend acceptance 
$(M=1.53)$. Adolescents coming from single-parent units reported more parent support $(M=1.69)$ and more communication with family members $(M=1.92)$ than their two-parent counterparts. Residential area of youth also was a significant variable. Therefore, we noticed that high school seniors living in rural areas reported more communication with parents $(M=1.74)$, more friend support $(M=1.54)$ and friend acceptance $(M=1.47)$ than their peers living in urban settings.

Table 5. Statistical significant relationships of the for demographic variables

\begin{tabular}{|c|c|c|c|c|c|c|c|c|c|}
\hline \multirow[t]{2}{*}{ Variable } & \multicolumn{2}{|c|}{ Gender } & \multirow[t]{2}{*}{$t$} & \multicolumn{2}{|c|}{ Family unit } & \multirow[t]{2}{*}{$\bar{t}$} & \multicolumn{2}{|c|}{ Residency } & \multirow[t]{2}{*}{$t$} \\
\hline & Male & Female & & $\begin{array}{l}\text { Single- } \\
\text { parent }\end{array}$ & $\begin{array}{l}\text { Two- } \\
\text { parent }\end{array}$ & & Urban & Rural & \\
\hline $\begin{array}{l}\text { Family } \\
\text { togetherness }\end{array}$ & & & & $\begin{array}{l}1.69 \\
(0.54)\end{array}$ & $\begin{array}{l}1.30 \\
(0.39)\end{array}$ & $-3.87^{47+}$ & & & \\
\hline $\begin{array}{l}\text { Home } \\
\text { academic } \\
\text { environment }\end{array}$ & $\begin{array}{l}1.79 \\
(0.46)\end{array}$ & $\begin{array}{l}1.63 \\
(0.43)\end{array}$ & $-9.59^{.004}$ & $\begin{array}{l}1.92 \\
(0.43)\end{array}$ & $\begin{array}{l}1.68 \\
(0.45)\end{array}$ & $-2.82^{* 4}$ & $\begin{array}{l}1.67 \\
(0.45)\end{array}$ & $\begin{array}{l}1.74 \\
(0.46)\end{array}$ & $-4.20^{\circ+7}$ \\
\hline $\begin{array}{l}\text { Friend } \\
\text { support }\end{array}$ & $\begin{array}{l}1.48 \\
(0.53) \\
\end{array}$ & $\begin{array}{l}1.43 \\
(0.51)\end{array}$ & $-2.43^{\circ *}$ & & & & $\begin{array}{l}1.39 \\
(0.50)\end{array}$ & $\begin{array}{l}1.54 \\
(0.52)\end{array}$ & $-7.78^{\text {WW }}$ \\
\hline $\begin{array}{l}\text { Peer-group } \\
\text { acceptance }\end{array}$ & $\begin{array}{l}1.53 \\
(0.34)\end{array}$ & $\begin{array}{l}1.39 \\
(0.30)\end{array}$ & $-11.35^{\circ+4}$ & & & & $\begin{array}{l}1.43 \\
(0.32)\end{array}$ & $\begin{array}{l}1.47 \\
(0.34)\end{array}$ & $-3.54^{0.04}$ \\
\hline
\end{tabular}

Communication with family members and peers and personal future planning

After this descriptive picture on the levels of support and personal plans of adolescents was drawn, we asked ourselves whether is there a combination of background information, family and peer support variables that would predict future plans of adolescents. Therefore, a set of multiple binary logistic regressions was run to predict personal and professional future plans using family support, home academic environment, peer support, peer acceptance, gender, family type and residency as predictors. Table 6 summarizes the results with odds ratio in parentheses. A significant odds ratio with a value below 1 indicates that the independent variable reduces the odds of the dependent variable having a value of 1 (specific plan for the near future), and an odds ratio greater than 1 indicates an increase in these odds. 
Subtracting 1 from the ratio and multiplying by 100 gives the percent change in the odds of the dependent variable having a value of 1 (DeMaris 1995).

All the five models proved statistically significant, indicating that the predictors were able to distinguish between the two groups of interest (those having/not having a specific plan).

Table 6. Summary of Multiple Logistic Regression Analysis for Variables Predicting Future Planning for Adolescents

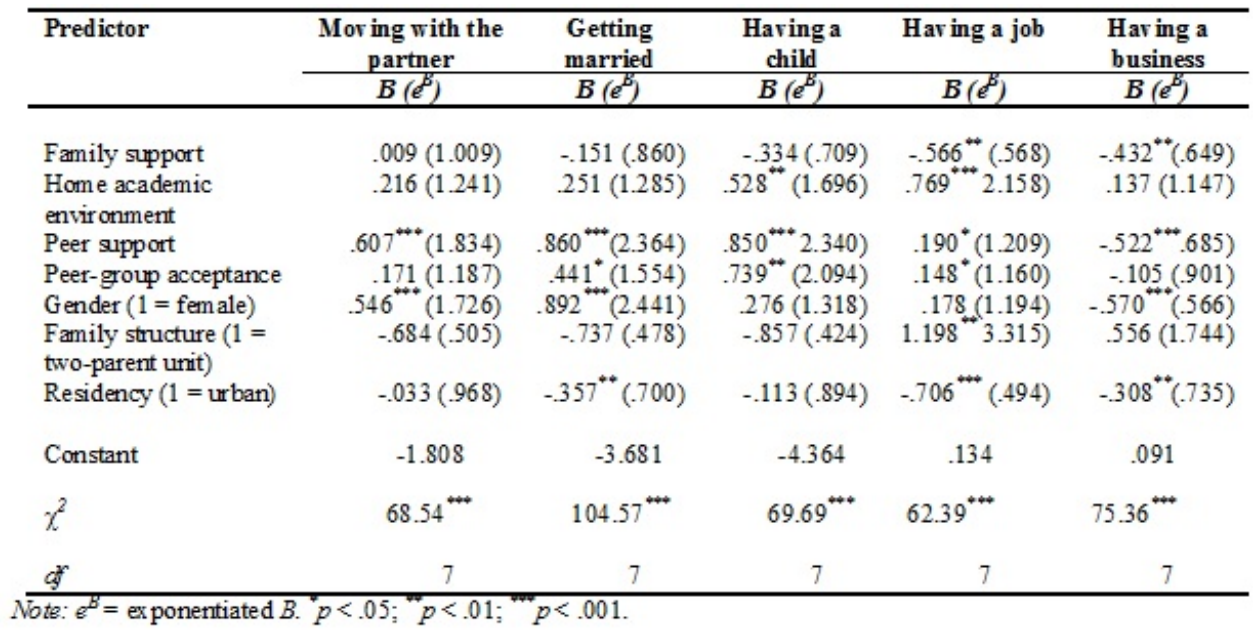

Thus, the odds ratio for family support (.56 for having a job and .64 for having a business) indicates that every unit increase in this variable (e.g., more intense the feelings of emotional closeness and bonding with family members, of doing things together, and working together to solve problems) is associated with a $44 \%$ decrease in the odds of planning having a job and with a $36 \%$ decrease in the odds of thinking starting a business. In other words, youth from these families were significantly less likely to develop any professional plan for the following 2-3 years.

Contrary to this, the degree of which youth report discussing with family different topics had a positive effect on having a child and having a job. The odds of having a child are 1.69, respectively 2.15 higher for youth 
who tackle subjects like their courses or programs at school, their schoolrelated activities, current events and politics, or their plans for the future.

Peer-support is the most significant variable. Its positive effect is noticed in all the models, except in 'having a business'. It looks like that youth with higher peer-support had 32\% less chances in starting thinking of an own business. But all the personal plans are positively associated to this variable. Every unit increase in peer-support (more trustworthy, supportive and responsive friends are to their needs and feelings) meant that adolescents were almost two times more likely to plan moving with the partner and more than two times more likely to plan getting married or having a child. Peer-acceptance also had a positive effect. More youth felt accepted by their peers, able to be themselves, and able to resist peer pressure, more likely they were to plan getting married or having a child.

As a general picture, it seems that family-related variables intervened more on developing the prospective professional plans, but their effect was negative, while friend-related variables had a greater positive effect on developing personal plans. This might be due to the developmental stage adolescents are. At this age, friends play a more important role than family is.

The background information (gender, family-type and residency) played different roles in the regression models. As expected, the females were more likely to report plans about family ('moving with the partner' or 'having a child'), while males were more likely to plan 'having a business'. When controlling for all the other regressed variables, the greatest effect of gender was for 'getting married'. The odds for females were 2.44. Family structure was associated to the plan of 'having a job'. Compared with peers from single-parent units, youth from two-parent family structures were 3.31 more likely to have a job in the near future. Residency was associated with professional plans ('having a job' or 'having a business'). Youth from urban areas were less likely to think about a career option for the near future. 


\section{Conclusions}

After exiting formal education system, high school seniors must take an important decision regarding their future educational, occupational or personal path. The choices they make can shape, but do not necessarily determine, the course of their lives. Therefore, our data are far from imposing a deterministic perspective about emerging adulthood. Previous literature argued that adolescents' plans are influenced by complex of social and individual factors, such as the type of information they are exposed to as well as community norms and values (Akos et al. 2007; Bandura et al. 2001). Nurmi (1991) argues that adolescents are mostly concerned about their future education and professional roles. These types of aspirations are supposed to be more malleable for teenagers because they are strongly shaped by attitudes of parents, teachers, and peers (Akos et al. 2007).

We may conclude that adolescents' life paths are shaped by the kinds of people they encounter during the years and by the experiences they have (Ellison, Wohn and Greenhow 2014). Assuming that there is a pressure of making 'the wrong choice', measuring the degree adolescents base their future options on personal or social factors is the key to understanding how the decision could affect later life outcomes. The current study examined the relationships adolescents have with their family and peers and the development of a specific future personal or professional decision. This is important in practice as earlier research has shown that having a personal goal in a certain area improves self-regulation in that domain (Oyserman 2001). Personal goals serve to guide and regulate behaviour, providing a road map connecting the present to the future (Karoly 1993).

Future planning of youth has been explored in different ways and has consistently been found to relate to later adult competences and attainments (Manzi, Vignoles and Regalia 2010). Overall, for the variables analysed, adolescents have positive relations (in terms of communication and support) both with parents and peers. The regression models used in explaining their future plans were statistically significant. Even if the explanatory value for these models accounted for less than 10\% (between 3-5.4\% - Cox and Snell R 
square and 5-9.7\% - Nagelkerke R squared), the following general conclusions emerged:

- $\quad$ Peer support concluded as being the most significant variable in setting all the measured outputs of future planning (moving with the partner, getting married, having a child, having a job, and starting their own business). Adolescents with higher levels of support from their peers are more likely to plan moving with the partner, getting married, having a child and having a job, but less likely to plan having a business in the near future. We are aware that these plans do not cover the entire set of options high school seniors have at their high school graduation. Therefore, other plans and other explanatory variables might occur. However, previous studies have shown that parental influence on the adolescent's aspirations is stronger than peer influence, and this influence does not decline over the adolescent years (Davies and Kandel 1981).

- The lower the family support is, more likely senior high school students are to plan a career option;

- $\quad$ Females are more likely to plan moving with the partner and getting married, but less likely to think about professional option;

- $\quad$ Youth from rural areas are more likely to think about getting married or a career option.

All these need to be supported by further analysis with other conceptual models being tested. For instance, it might be noted that other factors (e.g. personal competence) could explain better the future plans of adolescents.

\section{Limitations}

These findings might inform social work practice in several ways. However, accompanying the study's contributions are several limitations. Using data on public school students that attend school limits the generalizability of the results. Also, the cross-sectional data are not well suited for identifying 
causal relationships. Because there are plans to track the sample's respondents into their early adult years, it will be possible to examine how well adolescents' expectations and desires about future predict their actual behavior. Doing so would add to the limited information and expand our knowledge in the field of social work intervention programs.

\section{Acknowledgement}

This study was funded through the project Outcomes of adolescence. A longitudinal perspective on the effects of social context on successful life transitions (PN-II-ID-PCE-2011-3-0543) financed by Executive Unit for Financing Higher Education, Research, Development and Innovation (UEFISCDI).

\section{References}

Akos, Patrik, Glenn W. Lambie, Amy Milsom and Kelly Gilbert. 2007. “Early adolescents' aspirations and academic tracking: An exploratory investigation." Professional School Counseling 11 (1): 57-64.

Bandura, Albert, Claudio Barbaranelli, Gian Vittorio Caprara and Concetta Pastorelli. 2001. "Self-efficacy beliefs as shapers of children's aspirations and career trajectories." Child Development 72 (1): 187-206.

Barnett, Rosalinda C., Karen C. Gareis, Jacquelyn B. James and Jennifer Steele. 2003. "Planning ahead: College seniors' concerns about careermarriage conflict." Journal of Vocational Behavior 62 (2): 305-319.

Cairns, Robert B. and Beverley D. Cairns. 1994. Lifelines and Risks: Pathways of Youth in Our Time. Cambridge: Cambridge University Press.

Conger, Rand. D, Ming Cui, Chalandra M. Bryant and Glen H. Elder Jr. 2000. "Competence in early adult romantic relationships: a developmental perspective on family influences." Journal of Personality and Social Psychology 79 (2): 224-37.

Davies, Mark and Denise B. Kandel. 1981. "Parental and peer influences on adolescents' educational plans: Some further evidence." American Journal of Sociology 87 (2): 363-387.

DeMaris, Alfred. 1995. "A tutorial in logistic regression." Journal of Marriage and the Family 57 (4): 956-968. 
Ellison, B. Nicole, Yvette D. Wohn and Christine M. Greenhow. 2014. "Adolescents' visions of their future careers, educational plans, and life pathways: The role of bridging and bonding social capital experiences." Journal of Social and Personal Relationships 31 (4): 516-534.

Farmer, Helen S. 1985. "Model of career and achievement motivation for women and men." Journal of Counseling Psychology 32 (3): 363-390.

Felsman, Debra E. and David L. Blustein. 1999. "The role of peer relatedness in late adolescent career development." Journal of Vocational Behavior 54 (2): 279-295.

Fisher, Teresa A. and Mildred B. Griggs. 1995. "Factors that influence the career development of African-American and Latino youth." The Journal of Vocational Education Research 20 (2): 57-74.

Furstenberg, Frank F., Thomas D. Cook, Jacquelynne Eccles, Glen H. Elder and Arnold Sameroff. 1999. Managing to Make It: Urban Families and Adolescent Success. Chicago, IL: University of Chicago Press.

Hărăguş, Paul, Maria Roth and Diana Dămean. 2010. "The Measurement of the Social Dimensions of School Success - A Validity Study of teh Romanian Version of School Success Profile." Studia Sociologia LV (1): 31-55.

Iovu, Mihai B. 2013. "Senior high school students' job planning for the future: what factors really matter?" Revista de Asistență Socială 1: 5970.

Iovu, Mihai B., Paul T. Hărăguş, Maria Roth, Sergiu Raiu, Agnes KacsoDavid, Csaba Degi, Cristina Faludi, Corina Voicu and Anna Vincze. 2013. “Adolescents' Plans for Family Formation. Preliminary Findings from Romania." Revista de Asistență Socială 3: 131-143.

Karoly, Paul. 1993. "Goal systems: An organizing framework for clinical assessment and treatment planning." Psychological Assessment 5 (3): 273-280.

Maines, David R. and Monica J. Hardesty. 1987. "Temporality and gender: Young adults' career and family plans." Social Forces 66 (1): 102-120.

Manzi, Claudia, Vivian L. Vignoles and Camillo Regalia. 2010. "Accommodating a new identity: Possible selves, identity change, and well-being across two life-transitions." European Journal of Social Psychology 40 (6): 970-984.

McCabe, Kristen and Douglas Barnett. 2000. "First comes work, then comes marriage: Future orientation among African American young adolescents." Family Relations 49 (1): 63-70. 
Oyserman, Daphna 2001. "Self and identity." In Blackwell handbook of social psychology, edited by Abraham Tessor and Norbert Schwarz, 499-517. New York: Oxford University Press.

Rarasati, Niken, Moh A. Hakim and Kwartarini W. Yuniarti. 2012. "Japanese Adolescents' Future Orientation and Support for its Effort: An Indigenous Psychological Analysis." World Academy of Science, Engineering and Technology 6 (6): 597-601.

Roth, Maria, Agnes Kacso-David, Mihai Iovu, Anna Vincze, Paul Hărăguş, Csaba Degi, Corina Voicu and Cristina Faludi. 2012. "Outcomes of Adolescence in Romania." Procedia - Social and Behavioral Sciences 69: 1959-1964.

Runcan, Patricia and Cosmin Goian. 2013. "Career aspiration of social work students from Romania." Social Work Review 1: 103-110.

Schoon, Ingrid and Samantha Parsons. 2002. "Teenage Aspirations for Future Careers and Occupational Outcome." Journal of Vocational Behavior 60 (2): 262-288.

Seltzer, Judith A. 2000. "Families formed outside marriage." Journal of Marriage and Family 62 (4): 1247-1268.

Sipe, Stephanie, Johnson C. Douglas and Donna K. Fisher. 2009. “University Students' Perceptions of Gender Discrimination in the Workplace: Reality versus Fiction." Journal of Education for Business 84 (6): 339349.

Starrels, Marjorie E. and Kristen E. Holm. 2000. “Adolescents' Plans for Family Formation: Is Parental Socialization Important?" Journal of Marriage and the Family 62 (2): 416-429.

Stattin, Håkan and Margaret Kerr. 2001. "Adolescents' Values Matter." In Navigating Through Adolescence: European Perspectives, edited by JariErik Nurmi, 21-54. New York: Routledge Falmer.

Steinberg, Laurence D. 2004. The ten basic principles of good parenting. New York: Simon \& Schuster.

Steinberg, Laurence, Sandra Graham, Lia O'Brien, Jennifer Woolard, Elizabeth Cauffman and Marie Banich. 2009. "Age Differences in Future Orientation and Delay Discounting." Child Development 80 (1): 28-44.

Trempala, Janusz and Lars-Erik Malmberg. 2002. Adolescents' future orientation. Theory and Research. New York: Lang. 